\title{
Aspekte Van Die Gesondheidsvoorligtingstaak Van Die Gemeenskapgesondheidsverpleegster
}

\author{
Elma Grobbelaar, \\ Mede-professor, Departement Verpleegkunde, \\ Universiteit van S.A.
}

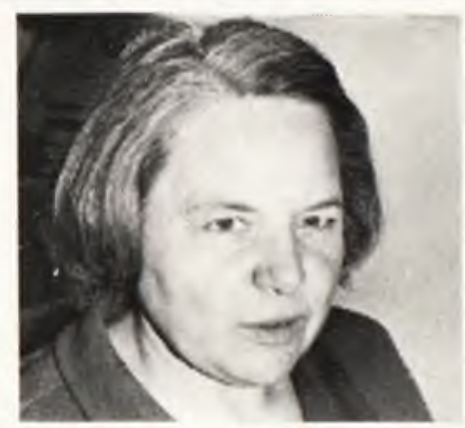

\section{SUMMARY}

Health education is never-ending. It should be basic to the philosophy of the health worker and especially of the community health nurse. She stands at the heart of the community, knows the people and therefore bears a heavy responsibility to inspire them, help them to gain insight and lead them to take initiative. The success of her work as a whole will be measured by her guidance of the community as such to accept and experience as a way of life the promotion of health at all levels.

G ESONDHEIDS VOORLIGTING (bevordering),

hoewel 'n nuwe begrip, is so oud soos die mens self. Dit het deel gevorm van die geneeskundige en religieuse begrippe soos beoefen deur die priester-geneesheer sedert die vroegste tye. "n Goeie voorbeeld is die gesondheidswette wat soos in die Ou Testament weergegee, aan die Israeliete voorgehou was. Meeste religieuse gelowe en bygelowe, selfs die mees primitiewe bygelowe. bevat elemente van gesondheidsvoorligting

Van al die funksies van die gemeenskapsgesondheidsverpleegster is dit egter gesondheidsvoorligting wat vroeër in hierdie eeu die minste aandag geniet het. Gesondheids-" opvoeding" het vir dekades in die skaduwee van grootskaalse diens en omgewingsgesondheidsprogramme gestaan en het slegs sporadies in die vorm van inligtinggewende programme opgeduik. byvoorbeeld inligting oor siektes soos tuberkulose. polio, hartsiektes en kindervoeding. Om egter kennis te dra van kardiovaskulêre siektes is een ding. maar om so te lewe om die toestande te voorkom is heeltemal 'n ander saak. Dit is juis hierdie onderskeid tussen kennis en belewing wat gesondheidsbevordering belangrik maak vir die mens.

Duidelikheidshalwe is dit nodig dat sekere terme omskryf word:

Die begrip gesondheid verskil van mens tot mens - die definisie van die W.G.O. is aan almal bekend en word nie herhaal nie. Gesondheid (health) is afgelei van die Anglo-
Saksiese woord wat "veilig". " geheel" (volkome) beteken. In breë konteks dui dit op die fisiese, verstandelike, geestelike, emosionele en sosiale komponente van die mens dit het te doen met hoe die mens voel, sy leefwyse en hoe hy teenoor ander en in sy gemeenskap optree.

"Gesondheid" het "n relatiewe betekenis en verskil van mens tot mens. Sommige persone ondervind 'n hoër graad van welsyn as ander. Die gesondheid van alle individue wissel ook van tyd tot tyd. Meeste mense aanvaar gesondheid as vanselfsprekend en doen min om hulself teen siekte/ongeluk te beskerm en ongesteldheid word as 'n ongerief en las beskou wat die daaglikse roetine omvergooi. Dit is egter belangrık dat elke individu weet hoe om gesondheid te verwerf en dit te behou.

in Gemeenskapgesondheidverpleegster is 'n professionele gesondheidswerker wat gemoeid is met gemeenskapgesondheidverpleegkunde en as lid en dikwels as die leier van die gesondheidspan in die gemeenskap, 'n omvattende gesondheidsdiens lewer.

Gesondheidsvoorligting in die verpleegkonteks is gemoeid met elke fase van die mens se lewe. Die doel is om individue en groepe te help om gesond te wees, of die mate van "gesondheid" wat hulle besit ten volle te benut. Voorligting is om mense voor te lig. en nie net in te lig nie, maar om mense te lei tot insig in gesondheidsake. om dan hul kennis en ondervinding so aan te wend dat dit 'n voordelige invloed sal hê op die fisiese, geestelike en sosiale welsyn en 
die leefwyse van die mens. Dit is "n motivering van positiewe gesonde optrede en nie slegs die oordra van kennis oor sekere siektes nie. Die WW.G.O. beskou gesondheidsvoorligting as 'n belangrike essensiële element van die gesondheidsprogram wat afhanklik is van die aktiewe deelname van 'n goedingeligte publiek.

Die S.A. Nasionale Raad vir Gesondheidsvoorligting meen dat gesondheidsvoorligting noodsaaklik is vir elke sektor van die bevolking, dat alle sektore van die bevolking bewus gemaak moet word van die direkte verwantskap tussen gesondheid van die gemeenskap en sy potensiaal vir sosio-ekonomiese ontwikkeling en dat alle mense deel het in hul eie gesondheid sowel as in die gesondheid van die gemeenskap as geheel. (5, p. 8)

Die Sekretaris van Gesondheid het in 1977 in sy openingsrede van die simposium oor gesondheidsvoorligting die volgende aangehaal: "if a modern health team wishes to ensure its components in fulfilling its responsibilities, then it must admit into the inner circle of the team a new and so far most unfamiliar partner: the public itself."' $(5$, p. 8$)$

Dit is dus die taak van elke lid van die gesondheidspan om deeglike kennis te dra nie net van die opvoedkundige metodes wat aangewend kan word om gesondheid van die mense in die gemeenskap te bevorder nie, maar ook om die mense te leer om self deel te neem aan gesondheidsvoorligting en gebruik te maak van die beskikbare gesondheidsdienste.

\section{DOELSTELLINGE VAN GESONDHEIDSVOORLIG- TING}

Gesondheidsvoorligting is 'n belangrike deel van 'n omvattende gesondheidsdiens en vorm 'n essensiële deel van veral voorkomende gesondheid. Gesondheidsvoorligting/bevordering se vernaamste taak is om die houding en gedrag van mense te verander deur die insig wat hulle kry, sodat hulle behoorlik oordeel oor 'n aangeleentheid kan fel. Dit moet hulle ook inlig oor daardie faktore wat hul gesondheid bedreig. Die mense moet gelei word om self deel te hê aan die instandhouding en bevordering van sy eie gesondheid sowel as die gesondheid van sy medemens. Hieruit blyk dat die primêre doelstelling van gesondheidsvoorligting is om mense te help om deur eie besluit ' $n$ leefwyse te ontwikkel wat gesondheid sal bevorder en siekte sal strem.

Om die doelstellings van gesondheids voorligting te bereik moet dit ' $n$ integrale deel vorm van die omvattende gesondheidsdiens van 'n land en elkeen wat met die diens gemoeid is moet deelneem aan gesondheidsvoorligting. ' $n$ Dinamiese gesondheidsvoorligtingsprogram is belangrik en daarsonder is ' $n$ gesondheidsdiens nie volledig nie. Elke lid van die gesondheidspan moet deel hê aan gesondheidsvoorligting en deeglik daarvoor toegerus wees.

\section{TAAK VAN DIE GEMEENSKAPGESONDHEIDSVER- PLEEGSTER}

Die verpleegster in Suid-Afrika staan in die sleutelposisie van gesondheidsorg en het daarom ook 'n belangrike en dinamiese rol as gesondheidsvoorligter.

Die W.G.O. glo dat gesondheidsvoorligting in elke verplegingsaktiwiteit vanselfsprekend is. Of sy nou verpleegsorg aan 'n siek of gebreklike persoon in 'n hospitaal, tuis, in die skool of industrie bied, of sy as gesondheidsraadgewer in ' $n$ kliniek of tuis optree, en of sy saam met ander lede van die span deelneem aan dic ontleding en beplanning van gesondheidsbehoeftes van 'n gemeenskap. daar is altyd geleentheid vir gesondheidsvoorligting. $(6, p$. 13)

Die persoonlike diens aan 'n pasiënt of gesin of gemeenskap bied belangrike geleenthede vir gesondheidsvoorligting. Vir die gemeenskapgesondheidsverpleegster wat in die gemeenskap met en tussen die mense werk en wat die gemeenskap ken en verstaan is daar talryke kanse vir gesondheidsvoorligting/bevordering.

$\mathrm{Om}$ as gesondheidsvoorligter op te tree vere is van die gemeenskapgesondheidsverpleegster dat sy:

- 'n deeglike kennis sal hê van haar gemeenskap (bv die samestelling, sosio-ekonomiese toestande. kulturele samestelling, wetgewing ens)

- deeglike insig in die faktore wat die gesondheid van die spesifieke gemeenskap sal beinvloed bv geografiese ligging, reënval, vervoer, voedselproduksie en sulke aspekte wat die leefwyse van die mens beinvloed sal hê

- goeie kennis sal dra van siektetoestande en veral van dié wat in die gemeenskap voorkom

- kommunikasievaardighede bemeester sodat sy nie net die kennis kan oordra nie maar ook die mense sal kan beinvloed om die verantwoordelikheid van hul eie gesondheid sowel as vir die gesondheid van die gemeenskap te help dra.

Die gemeenskapgesondheidsverpleegster moet dus haar taak as gesondheidsvoorligter sien in die lig van om ander te help om hul eie gesondheid te bevorder asook dié van die gemeenskap. Die individu oefen beheer uit oor sy eie gedrag en dit is hyself wat besluite neem behalwe in die geval van kinders waar die gesin die rol vervul. Dit berus dus by die individu/gesin of hulle hul eie gesondheid wil bevorder. Dit is dus hul persoonlike verantwoordelikheid. Die gemeenskapgesondheidsverpleegster se taak as gesondheidsvoorligter lê dus verder daarin dat sy die individu/gesin moet motiveer en help om hierdie verantwoordelikheid te aanvaar.

\section{FAKTORE WAT GESONDHEIDSVOURLIGTING/ BEVORDERING BEINVLOED}

Die gemeenskapgesondheidsverpleegster moet kennis dra van faktore wat gesondheidsvoorligting kan beinvloed en hierdie faktore moet in ag geneem word as sy van die gesondheidsvoorligting " $n$ sukses wil maak.

In Suid-Afrika met sy heterogene bevolking sal sy allereers 'n deeglike studie moet maak van die sosiale en kulturele eienskappe en praktyke van die gemeenskap en individue wat sy bedien. Kulturele gebruike en houdings ten opsigte van puberteit. swangerskap, eetgewoontes. higiëniese praktyke, beïnvloed die gesondheid van 'n gemeenskap. Die gemeenskapgesondheidsverpleegster sal nie net die kulturele gewoontes en gebruike in ag moet neem 
nie maar ook die sosiale organisasie van gesinne, geloot, praktyke van werkverdeling tussen geslagte en belangriker nog. die rol van die tradisionele gemeenskapsleiers en genesers.

Behalwe die erkenning van kulturele praktyke en die waarde van baie van die praktyke moet die gemeenskapgesondheidverpleegster ook die sosiale grense in ag neem. Faktore soos sosiale stande, peil van onderwys, ekonomiese status, taal en selfs geloof veroorsaak onoorkomelike sosiale grense tussen die gemeenskapgesondheidsverpleegster en die individu. Dit is veral van toepassing in die meer konserwatiewe. kultuurvaste gemeenskappe.

Om hierdie probleem te oorkom kan die geregistreerde verpleegster gebruik maak van die waardevolle kollega, die ingeskrewe verpleegassistent, wat gewoonlik 'n persoon van en uit die gemeenskap is. Hierdie persoon moet deur die gemeenskapgesondheidsverpleegster volledig onderrig word in die beginsels van gesondheidsvoorligting en moet voortdurend leiding in dié verband kry.

\section{ONDERRIGBEGINSELS}

Gesondheidsvoorligting beklemtoon die konsep van individuele verantwoordelikheid. die hulp aan die individu om kennis en vaardighede te leer. en hiervoor word insig wat baseer is op feitelike kennis van die verpleegster vereis. Voorligting geskied waar daar 'n ontmoeting is tussen twee persone. die een wat weet en voorligting gee. en die ander persoon wat wil leer. Omdat hy "n denkende mens is, is hy ont vanklik vir dit wat aan hom voorgehou word. Hy het ' $n$ eie wil en siening en onderwerp hom aan die lering slegs as hy wil. Daarom moet dit wat aan hom voorgehou word verband hou met sy werklikheid, sy behoeftes en sy belangstelling. Dit moet " $n$ uitdaging aan hom rig en hom dan inspireer en aktiveer.

Dit is nodig om te onderskei tussen onderrig wat meer te doen het met die ontwikkeling van die intellek en motoriese vaardighede terwyl voorligting gemik is op die vordering van die hele persoon. Dit beïnvloed ook sy wil en emosies. Dit het veral te doen met positiewe vorming van die morele karakter en die hele persoonlikheid van die mens.

In gesondheidsvoorligting sien ons die ontwikkeling van selfvertroue in persoonlike gesondheidsorg en die vermoë om korrek op te tree. Die konsep "vorming" ("moulding") word dikwels in opvoedkundige en gesondheidsliteratuur gevind. Dit moet gesien word in die lig van vorming van die individu deur al die invloede van die totale omgewing op die individu. Vorming kan positief of negatief wees. dit kan deurdag of onopsetlik geskied en dit vind dwarsdeur die mens se lewe plaas. In gesondheidsvoorligting is dit "n algemene konsep omdat dit dikwels die taak van die voorligter is om die invloed van die omgewing te bevorder of te bekamp.

\section{BEPLANNING VAN GESONDHEIDSVOORLIGTING}

'n Effektiewe en doeltreffende gesondheidsdiens vereis deeglike beplanning; net so ook is deeglike beplanning vir gesondheidsvoorligting nodig. Die W.G.O. konsultante glo dat beplanning van gesondheidsvoorligting die vermoë om die opvoedkundige en kennistekorte van individue of groepe te diagnoseer en dit aan te vul moet bevorder. 'n Voorvereiste hiervoor is om al die kennis wat ingesamel is oor die omgewing. siektetoestande. beskikbare gesondheidshulobronne, ekonomiese stand, sosiale gewoontes ten opsigte van gesondheid en die invloede wat onderskeie lede van 'n gesin/gemeenskap het op gesondheid te verwerk met inagneming van die belangstelling en behoeftes van die gemeenskap.

\section{VOORBEREIDING VAN GESONDHEIDSVOORLIG- TERS}

Die volgende aspekte moet beklemtoon word in die opleiding en voorbereiding van al die gesondheidswerkers wat gemoeid is met gesondneidsvoorligting, en veral in die voorbereiding van die gemeenskapgesondheidsverpleegster:

- studie van interpersoonlike verhoudings tussen mense en veral tussen die onderskeie gesondheidswerkers in 'n gemeenskap sodat kennis en ondervinding uitgeruil kan word tot voordeel van die gemeenskap

- ontwikkeling van kommunikasievermoë

- aanleer van die vermoë om te luister, te leer en te onderrig op "n persoonlike sowel as 'n gemeenskapsvlak

- die kuns om te beplan, organiseer en die opvoedkundige projekte aan te voer en te evalueer moet bemeester word

- gewilligheid om van ander te leer en saam met ander lede van die gesondheidspan en ander werkers te werk

- insig te hê in die funksies, verantwoordelikhede, belangstelling en behoeftes van alle kategorië gesondheidswerkers sowel as kennis dra van opvoedkundige instansies vir voortgesette onderwys. (7, p. 17-18)

\section{INHOUD}

Die inhoud van gesondheidsvoorligting sluit omtrent alle aspekte in wat die verpleegster in haar basiese kursusse dek met inagneming van die spesifieke gesondheidsprobleme en behoeftes van die betrokke gemeenskap. Slegs sommige aspekte van gesondheidsvoorligting van 'n aantal gesondheidsorgsituasies waarmee die gemeenskapgesondheidsverpleegster gemoeid is sal kortliks aangehaal word. Gesondheidsraadgewing in al die situasies behels alle aspekte van voorkoming van siektes en bevordering van gesondheid sowel as instandhouding van gesondheid en rehabilitasie.

\section{Gesondheidsvoorligting vir ouerskap}

Dit is een van die belangrike aspekte van voorligting wat dikwels afgeskeep word:

- voorligting aan jong manne en vroue in die gemeenskap ten opsigte van geestelike en fisiese gesondheid, gesonde sosiale houdings en gebruike en die aanvaarding van verantwoordelikhede van die huwelik en ouerskap 
- goed beplande voorligting oor gesinsbeplanning aan hierdie jongmense wat in die huwelik tree is uiters belangrik.

- genetiese raadgewing is ' $n$ belangrike onderwerp en het veral betrekking op die toekomstige ouers.

\section{Moeder- en kindersorg}

Dit is ' $n$ belangrike element van 'n omvattende gesondheidsdiens en gesondheidsvoorligting in hierdie afdeling sluit onder andere die volgende onderwerpe in:

- voor- en nageboortesorg

- versorging en voeding van die baba en jong kind; dit sluit in geestelike sowel as fisiese versorging

- voorligting aan vader en moeder en indien nodig aan ouer kinders in die gesin

- hantering van die jong gestremde kind.

\section{Skoolgesondheidsvoorligting}

Dit behels voorligting aan ouers, onderwysers en kinder. deur die gemeenskapgesondheidsverpleegster. Dit is veral in die ouer-onderwyser vereniging waar sy haar rol as gesondheidsraadgewer kan laat geld. Deur haar invloed kan sy die skool gebruik om gesondheidsprogramme te loods waarin skoolkinders in gemeenskapsversorging betrokke raak bv skoonhou van die omgewing, uitbreiding van sanitêre geriewe, voorkoming van waterbesoedeling en dienslewering van hierdie aard.

Die gemeenskapgesondheidsverpleegster het op dié gebied 'n belangrike rol, veral waar 'n omvattende gesondheidsdiens bestaan, omdat sy reeds die kinders as babas en kleuters ken en in die skool kan opvolg. Raadgewing aan die onderwyser is veral nodig ten opsigte van die fisiese en emosionele behoeftes van die gestremde kind sowel as die kind met gedragsafwykings en die voorkoming van sekere aansteeklike siektes.

Vir die tienderjariges in hoërskole, kolleges en koshuise is die volgende raadgewing besonder belangrik:

- die gebruik en misbruik van tabak, alkohol, gewoontevormende geneesmiddels, verslankingsmiddels

- verspreiding en voorkoming van veneriese siektes.

Dit is baie belangrik dat die jeugdige self betrek word deurdat hulle geleentheid gegee word om self programme te inisieer en aan te bied.

\section{Die adolessent en jong volwassene}

Adolessensie is ' $n$ kritieke periode van biologiese en psigologiese veranderinge vir die individu en vir baie mag dit ook verandering van die sosiale omgewing inhou. Hulle het reeds tot 'n mate gesondheidsvoorligting op skool gehad sodat meeste van hulle 'n basiese kennis van gesondheid het. Hierdie kennis kan uitgebrei word maar raadgewing moet egter in dié tydperk meer gemik wees op insig en aanvaarding van die persoonlike verantwoordelikheid vir sy eie gesondheid.
Die gemeenskapgesondheidsverpleegster sal in gesofistikeerde gemeenskappe nie so 'n groot rol in die lewe van dié ouderdomsgroep speel nie - dit is veral die universiteite, kolleges, ontspanningsklubs, ens waar voorligting gegee sal word.

In die minder gesofistikeerde gemeenskappe is die rol van die gemeenskapgesondheidsverpleegster vanweë omstandighede, dikwels veel meer omvattend vir hierdie groep individue. Die gemeenskapgesondheidsverpleegster kan met behulp van die skool, vroueverenigings, kerke, besighede en ander outoriteite die jeugdiges bereik. Die jeugdiges kan ook betrek word om gesondheids voorligting aan ander persone in die gemeenskap te gee en op so "n positiewe wyse leer hoe om hul verantwoordelikheid as burgers van die land te aanvaar.

Besonder ernstige geestes- en sosiale probleme word onder jeugdiges aangetref. Die sterftesyfer in dié ouderdomsgroep asook die selfmoordsyfer is skrikwekkend hoog veral in ontwikkelde lande. (4, p. 15-17 en bylaes). In dié opsig kan die gemeenskapgesondheidsverpleegster 'n belangrike rol speel deur gesondheidsvoorligting op so 'n wyse aan te bied dat dit aanvaarbaar is vir die jeugdiges en dat dit aansluit by hulle lewensfilosofie.

\section{Die werker}

Die grootste aantal individue in die arbeidsmag van 'n land word gevind in die ouderdomsgroep 17-70 jaar. Die werker benodig ook beskerming en raadgewing in verband met sy gesondheid. Beroepsgesondheidsprogramme behels meestal inspeksie van die omgewing, beroepsgesondheid en beheer van veiligheidsrisiko's of gevare, verskaffing van mediese dienste vir beserings en beroepsiektes. Dit is egter nie genoeg nie. In groter industrieë word gesondheidsvoorligtingsprogramme aangebied deur geneeshere, veiligheidsingenieurs, verpleegsters en werkgewers. Hoofsaaklik word inligting oor veiligheid en aanwending van veiligheidsmaatreëls en beheer van beroepsiektes gegee. (7, p. 800)

$\mathrm{Om}$ ' $\mathrm{n}$ doeltreffende gesondheidsvoorligtingsprogram vir die werker te ontwerp, is dit wenslik om indien moontlik, die werkgewer sowel as die outoriteite se ondersteuning, goedkeuring en samewerking te verkry vir die daarstelling van in omvattende gesondheidsdiens vir die werkers. Ook sal die behoeftes en belangstelling van die werkers bepaal moet word. Die effektiewe implementering van toepaslike gesondheidsvoorligtingsprogramme hang af van die belangstelling en samewerking van die werker.

\section{Die bejaarde persoon}

Die doel van gesondheidsraadgewing van die bejaarde is om insig te kry in die aanpassing wat hulle sal moet maak wanneer hulle aftree. Raad moet ook gegee word in verband met gesonde leefwyse om siektetoestande te voorkom asook voorkomende maatrëls om hulle veiligheid en gesondheid te bevorder. Inligting oor bestaande hulpdienste is ook vir hier- 
die groep persone belangrik. Die herindiensneming van die bejaarde verg spesiale insig in hulle gesondheidsbehoeftes.

\section{Gesondheidsbevordering vir rehabilitasie van pasiënte}

Rehabilitasie kan omskryf word as die hervestiging van 'n persoon sodat hy sy oorblywende funksies en vermoëns optimaal kan verrig en aanwend om daardeur 'n produktiewe burger van die land te wees of om sy fisiese. geestelike en emosionele vermoë binne sy beperkings so goed as moontlik aan te wend.

Die gemeenskapgesondheidsverpleegster sal in die gemeenskap die rehabiliterende pasiënte teëkom. Die pasiënte word vroeër of later uit die hospitaal ontslaan om in die gemeenskap verder versorg te word. Gesondheidsvoorligting aan hierdie persone moet nou voortgesit of opgevolg word. Die doel is om die pasiënt en sy gesin te help om die gesondheidsprobleme van die spesifieke toestand waaraan die pasiënt ly te oorbrug. Om aan hierdie vere iste te voldoen sal die gemeenskapgesondheidsverpleegster oor volledige kennis van die algemene toestande wat sy in haar besondere omgewing sal teëkom moet beskik. Dit sal dus vir haar nodig wees om hierdie toestande deeglik te bestudeer asook die nuwer ontwikkeling ten opsigte van behandeling en rehabilitasie van die toestande.

\section{Algemeen}

Die gemeenskapgesondheidsverpleegster sal 'n belangrike rol speel ten opsigte van die volgende:

- kardiovaskulêre toestande

- gastro-intestinale toestande

- niertoestande

- vloeistof

- elektroliete en suurbasisbalans en die belangrikheid om dié balans te handhaaf deur aanwending van eenvoudige huishoudelike middels.

\section{METODES EN MEDIA}

Die metode en media word hepaal deur die omvang en inhoud van materiaal, en die betrokke individu/groep aan wie voorligting gegee gaan word. Informele onderrig kan op enige plek en tyd waar daar 'n ontmoeting is tussen die gemeenskapgesondheidsverpleegster en die individu plaasvind en is een van die belangrikste metodes wat aangewend kan word om gesondheidsvoorligting aan te bied, bv op huisbesoek, in 'n kliniek, tydens ondersoek van 'n pasiënt, wanneer 'n pasiënt behandel word, ens.

Tegnieke wat belangrik is met informele onderrig is waarneming. Iuister. doelgerigte gesels, stel en beantwoording van vrae en die stel van ' $n$ voorbeeld. (3, p. 70-73)

$\mathrm{Om}$ te verseker dat hierdie tegnieke suksesvol toegepas kan word is ' $n$ vertrouensverhouding tussen die persoon wat onderrig gee en die een wat voorligting ontvang. noodsaaklik. Vyf basiese elemente wat in so " $n$ voorligtingsituasie van toepassing is moet in ag geneem word, naamlik:

- wedersydse respek

- deelname aan besluitneming
- vryheid van spraak en beskikbare inligting

- wedersydse verantwoordelikheid ten opsigte van beplanning

- identifisering van aktiwiteite en evaluering.

\section{Gestruktueerde onderrig}

Dit is voorligting wat vooruit beplan word vir 'n spesifieke tyd. plek, en vir 'n spesifieke groep persone, bv 'n lesing/demonstrasie aan 'n groep moeders, onderwysers en kinders, of gemeenskapslede. Verskillende programme moet vir verskillende groepe beplan word. Dikwels word in suksesvolle program herhaaldelik vir verskillende groepe gebruik en dit is verkeerd. Elke groep het sy eie behoeftes en vir elke groep moet $n$ verskillende onderrigmetode aangewend word volgens die aard en samestelling van die groep

\section{Besprekingsmetode}

In hierdie metode word die onderwerp ingelei deur 'n desk undige en onder dié se leiding vind later bespreking oor die spesifieke onderwerp plaas. Dit is veral ' $n$ metode wat by volwassenes aangewend kan word.

\section{Demonstrasiemetode}

Dit kan baie effektief vir 'n groep of enkelinge toegepas word. ' $n$ Bedrewe demonstrasie moet vooraf beplan en geoefen word. Alle benodighede moet byderhand wees. Dit moet stapsgewys en stadig verrig word en alle persone moet elke stap kan volg. Die demonstrasie moet opgevolg word deur beoefening en herdemonstrasie deur die individu of enkelinge uit 'n groep en moet deeglık deur die groep bespreek word. Dit is ' $n$ metode wat veral van toepassing is by voorbereiding van voedsel. versorging van pasiënte met spesifieke probleme tuis, bv versorging van "n pasiënt met "n kolostomie.

Om hierdie metode en ander doeltreffend aan te wend word gebruik gemaak van verskillende onderrigmateriaal en media wat gekies en aangewend word om die leeraktiwiteite te versterk. So kan verskillende leeraktiwiteite en onderrigmedia aangewend word om 'n onderwerp te bespreek, bv " lesing kan aan 'n groep verwagtende moeders gegee word oor voorgeboortesorg en voortgesit word deur 'n bespreking van die onderwerp en afgesluit word deur "n demonstrasie van 'n dieet. oefeninge en kleding om die gesondheid van die moeder te bevorder.

Omdat gesondheidsvoorligting deel is van die normale leefwyse van die mens moet onderrigmateriaal en -media so gekies word dat natuurlike ondervindinge en media sover as moontlik gebruik word sodat die persone vir wie dit gebruik word hulle nie vergaap aan die media en dan geen baat vind by die voorligting self nie.

Voordat hulpmiddels aangewend word moet daar deeglik besin en beplan word en moet die sosiale, kulturele en ekonomiese stand van die mense, die soort voorligting, en die doel van gesondheidsvoorligting deeglik in verband 
gebring word. Dieselfde beginsel is van toepassing by die gebruik van massamedia.

Programme wat deur massamedia aangebied word moet gedurig hersien word vir 'n spesifieke doel in terme van onmiddellike of langtermyn gesondheidsbehoeftes.

Die doeltreffendste van al die metodes en media bly steeds gesondheidsvoorligting aan klein groepe of op individuele vlak waar kommunikasie op 'n horisontale vlak van aangesig-tot-aangesig of persoon-tot-persoon kan geskied.

\section{EVALUERING}

'n Laaste belangrike deel waarvan ook melding gemaak moet word is evaluering van die gesondheidsvoorligting wat aangebied was. Evaluering is 'n proses van waardering of bepaling van die waarde van "iets". Die "iets" kan 'n mens, 'n voorwerp, 'n aktiwiteit of 'n oortuiging wees. Evaluering vind daagliks oral plaas - elke dag, op elke gebied, word dinge, mense of oortuigings se waarde bepaal of ge-evalueer. Die vraag ontstaan "hoe" moet gesondheidsvoorligting ge-evalueer word.

Omdat leer ' $n$ intellektuele proses is en dit tyd en verdere ondervinding verg om dit wat geleer word te assimileer, is dit dus moeilik of bykans onmoontlik om dadelik te bepaal hoeveel die persoon begryp het van dit wat aan hom aangebied is. Evaluering van gesondheidsvoorligting sal dus oor 'n lang tydperk geskied en die voorligter sal mettertyd geleidelik kan vasstel of die persone aan wie voorligting gegee is insig het en of daar enigsins 'n verandering ten opsigte van gedrag of houding teenoor gesondheid plaasgevind het en ten laaste of daar enige bevordering van gesondheid in die gemeenskap is.

Die voorligter moet haarself objektief kan evalueer sodat sy op grond daarvan haar program of aanbieding van gesondheidsvoorligting kan wysig. Evaluering moet dus voortdurend plaasvind met die doel om die optrede van die persoon wat gesondheidsvoorligting aanbied meer effektief te maak.

Die gemeenskap en die gesondheidspan moet deelneem aan periodieke evaluering. Dit lei tot groter verantwoordelikheid, belangstelling en deelname in persoonlike maar ook die gemeenskap se gesondheidsbevordering.

\section{SLOT}

Gesondheidsvoorligting is nimmereindigend. Dit moet deel van die lewensbeskouing van die gesondheidswerker en veral van die gemeenskapgesondheidsverpleegster word. Sy is self lid van die gemeenskap; sy ken die mense en het daarom die verantwoordelikheid om hulle te besiel en te lei tot insig en selfoptrede. Die sukses van haar werk sal gemeet word aan hoe sy die gemeenskap gelei het om voorkoming en bevordering van gesondheid op alle vlakke as leefwyse te aanvaar en te beleef.

\section{BIBLIOGRAFIE}

1. Gunter, G. 1. C. Aspects of educational theory. Stellenbosch University Pub lishers \& Booksellers (Pty) Ltd.

2. Healih Education in Action. Vol. 7 Intemational Conference on Health Education 1962, W H O Geneva.

3. Pohl, M. L. The teaching function of the Nursing Practitioner. 2nd edition. 1973. W M C Brown Co Publishers, Dubuque, Iowa.

4. Report of a W H O Expert Committee Technical report series 609. W H O Geneva, 1977. Health needs of adolescents

5. Southern African Health Education Symposium. Conference proceedings, Oc tober 1977.

6. Technical Report Series 89. Expert Committee on Health Education of the Public, 1954, W H O, Geneva.

7. Technical Repon 156, Expert Committee on Training of Health Personnel in Health Education of the Public, 1958, W H O. Geneva

8. Volksgesondheid - Public Health. Deel $69 \mathrm{Nr} 8$, Augustus 1969. Instituut van Publieke Gesondheid, Johannesburg. 